\title{
Intraspecific molecular variation among Trichoderma harzianum isolates colonizing mushroom compost in the British Isles
}

\author{
S. Muthumeenakshi, ${ }^{1}$ P. R. Mills, ${ }^{1,2}+$ Averil E. Brown ${ }^{1,2}$ and D. A. Seaby ${ }^{2}$
}

Author for correspondence: P. R. Mills. Tel: +44903716123 ext. 2368. Fax: + 44903726780.

Department of Applied Plant Science, The Queen's University of Belfast, ${ }^{1}$ and Plant Pathology Research Division, Department of Agriculture for Northern Ireland, 2 Newforge Lane, Belfast, BT9 5PX, UK

\begin{abstract}
The genetic diversity in Trichoderma harzianum isolates from mushroom compost was assessed using various molecular techniques. Restriction fragment length polymorphism (RFLP) analysis of ribosomal DNA (rDNA) and mitochondrial DNA (mtDNA) divided the 81 isolates into three major groups, 1, 2 and 3 . There was no variation within a group in rDNA, while a low degree of polymorphism was detected in mtDNA. Random amplified polymorphic DNA (RAPD) analysis of 30 randomly chosen isolates, with six primers, in general confirmed the RFLP groups. Nucleotide sequence determination of rDNA internal transcribed spacer (ITS) 1 revealed three distinct ITS types, 1, 2 and 3, possessed by isolates from the respective groups 1, 2 and 3. Based on these molecular data, group 2 isolates, which are aggressive colonizers of mushroom compost, could be clearly distinguished from the isolates belonging to the other two groups.
\end{abstract}

Keywords: Trichoderma barzianum, mushroom compost, molecular variation, systematics

\section{INTRODUCTION}

Trichoderma, a common soil fungus, remains a potential threat to the mushroom industry following the green mould epidemic in the British Isles during 1985-86 and more recently in late 1990 and 1991. Losses have been estimated at $£$ 3-4 million to the UK and Irish mushroom industries (Fletcher, 1990). Trichoderma harzianum has most frequently been associated with aggressive colonization of mushroom compost, although $T$. viride, $T$. pseudokoningii, $T$. hamatum and T. longibrachiatum have also been isolated from compost (Seaby, 1989). The genus Trichoderma lacks a discrete species concept because of variation within and among species groups, defined as species aggregates by Rifai (1969). Bissett (1991) proposed 'sections' to accommodate morphologically similar forms within the species aggregates of Rifai (1969). T. harzianum isolates from mushroom compost all conform to the criteria currently used for identification of the species

fPresent address: Horticulture Research International, Wellesbourne, Warwick CV35 9EF, UK.

Abbreviations: ITS, internal transcribed spacer; mtDNA, mitochondrial DNA; RAPD, random amplified polymorphic DNA; RFLP, restriction fragment length polymorphism.

The EMBL/Genbank/DDBJ accession numbers for the nucleotide sequences reported in this paper are $X 73686$ to $X 73703$.
(Rifai, 1969); however, these have been differentiated into three biological forms termed Th1, Th2 and Th3 by Seaby (1987) and $z, x$ and y strains by Doyle (1991). These three groups of $T$. harzianum differ in their growth rate and time and pattern of sporulation when grown under specified cultural conditions; however, not all isolates can be reliably identified by these characters. T. harzianum isolates also differ in their aggressiveness in colonizing the compost in competition with Agaricus bisporus (Doyle, 1991).

In recent years, various molecular techniques have been used in the systematics of phytopathogenic and other (commercially important) fungi to assess intra- and interspecific variation and to determine phylogenetic relationships (Buchko \& Klassen, 1990; Chen et al., 1992; Förster et al., 1990; Gaudet et al., 1989; Levy et al., 1991; Moody \& Tyler, 1990a, b; O’Donnell, 1992; Vaillancourt \& Hanau, 1992). Meyer et al. (1992) used a DNA fingerprinting technique to analyse the nine species aggregates of Trichoderma and recognized only five groups. In the present study, we have used restriction fragment length polymorphism (RFLP) and random amplified polymorphic DNA (RAPD) analyses and sequencing of the internal transcribed spacer (ITS) 1 region in the ribosomal DNA gene block to estimate the intraspecific divergence among isolates of $T$. harzianum and to classify the aggressive Th2 isolates. 
Table 1. Source and rDNA, mtDNA and ITS 1 sequence groupings of $T$. harzianum isolates from mushroom compost

\begin{tabular}{|c|c|c|c|c|c|}
\hline No. & $\begin{array}{l}\text { Isolate } \\
\text { code }\end{array}$ & $\begin{array}{c}\text { rDNA } \\
\text { grouping* }\end{array}$ & $\begin{array}{c}\text { mtDNA } \\
\text { grouping* }\end{array}$ & $\begin{array}{c}\text { ITS } 1 \\
\text { sequence } \\
\text { type }\end{array}$ & $\begin{array}{c}\text { RAPD } \\
\text { analysis }\end{array}$ \\
\hline \multicolumn{6}{|c|}{ Northern Ireland $\dagger$} \\
\hline 1 & Th2A & 2 & $2 \mathrm{~d}$ & 2 & + \\
\hline 2 & Th2F & 2 & $2 \mathrm{~b}$ & & \\
\hline 3 & Th1H & 1 & 1a & & \\
\hline 4 & ThI & 2 & $2 \mathrm{~b}$ & 2 & + \\
\hline 5 & Th3K & 1 & 1a & & \\
\hline 6 & ThL & 1 & $1 \mathrm{~g}$ & & + \\
\hline 7 & Th1 M & 1 & $1 \mathrm{a}$ & & + \\
\hline $8-9$ & Th1 $(a, b)$ & 1 & 1a & & \\
\hline 10 & Th1 (c) & $i$ & $1 \mathrm{a}$ & & + \\
\hline 11 & Th2a & 2 & $2 e$ & & \\
\hline 12 & Th2b & 2 & $2 a$ & & \\
\hline 13 & Th3e & 1 & 1a & & \\
\hline $14-19$ & Th1 (1-6) & 1 & $1 \mathrm{a}$ & & \\
\hline 20 & Th1 (7) & 1 & 1f & & + \\
\hline 21 & Th1 (8) & 1 & if & & \\
\hline 22 & Th2 (1) & 2 & $2 \mathrm{a}$ & 2 & + \\
\hline $23-31$ & Th2 (2-10) & 2 & $2 a$ & & \\
\hline 32 & Th2 shiitake & 2 & $2 \mathrm{a}$ & & + \\
\hline $33-39$ & Th3 $(1,3,6,8,9,10,11)$ & 2 & $2 a$ & & \\
\hline 40 & Th3 (4) & 3 & $3 a$ & 3 & + \\
\hline 41 & Th3 (5) $\ddagger$ & 2 & $2 \mathrm{e}$ & & + \\
\hline 42 & Th3 (7) & 3 & $3 \mathrm{a}$ & 3 & \\
\hline 43 & Th3 McG & 3 & $3 e$ & 3 & + \\
\hline $44-47$ & $S(1,3,4,5)$ & 1 & $1 \mathrm{a}$ & & \\
\hline 48 & $S(6)$ & 2 & $2 \mathrm{~d}$ & & \\
\hline $49-50$ & $S(7,9)$ & 2 & $2 a$ & & \\
\hline 51 & TD1 & 1 & $1 \mathrm{~g}$ & 1 & \\
\hline 52 & TD2 & 1 & $1 \mathrm{a}$ & & \\
\hline 53 & TD3 & 2 & $2 \mathrm{a}$ & & \\
\hline 54 & TD5 & 3 & $3 \mathrm{~b}$ & & \\
\hline 55 & TD6 & 3 & $3 a$ & & + \\
\hline 56 & TD7 (IMI 359825) & 3 & $3 \mathrm{~b}$ & 3 & + \\
\hline 57 & TD12 & 1 & $1 \mathrm{e}$ & 1 & + \\
\hline 58 & TD13 & 1 & $1 \mathrm{~d}$ & & + \\
\hline 59 & TD15 & 1 & $1 \mathrm{a}$ & 1 & + \\
\hline \multicolumn{6}{|c|}{ England $\uparrow$} \\
\hline 60 & KPNT $\ddagger$ (IMI 359824) & 2 & $2 e$ & 2 & + \\
\hline 61 & $\mathrm{~T} 7 \mathrm{JF}$ & 2 & $2 \mathrm{e}$ & & \\
\hline 62 & $\mathrm{~T} 8 \mathrm{JF}$ & 2 & $2 \mathrm{e}$ & & \\
\hline 63 & T9 JF & 2 & $2 \mathrm{e}$ & & + \\
\hline 64 & $\mathrm{~T} 11 \mathrm{JF}$ & 3 & $3 \mathrm{~d}$ & 3 & + \\
\hline 65 & $\mathrm{~T} 13 \mathrm{JF}$ & 2 & $2 c$ & & + \\
\hline 66 & $\mathrm{~T} 18 \mathrm{JF}$ & 3 & $3 \mathrm{~d}$ & & + \\
\hline 67 & $\mathrm{~T} 20 \mathrm{JF}$ & 1 & $1 \mathrm{a}$ & & \\
\hline 68 & $\mathrm{~T} 23 \mathrm{JF}$ & 1 & $1 \mathrm{~b}$ & & + \\
\hline 69 & $\mathrm{~T} 24 \mathrm{JF}$ & 2 & $2 \mathrm{~d}$ & & \\
\hline 70 & T26JF & 1 & $1 \mathrm{a}$ & & \\
\hline 71 & T28JF‡ (IMI 359823) & 1 & $1 \mathrm{a}$ & 1 & + \\
\hline 72 & $\mathrm{~T} 35 \mathrm{AJF}$ & 1 & $1 \mathrm{c}$ & & \\
\hline 73 & $\mathrm{~T} 35 \mathrm{BJF}$ & 1 & $1 c$ & & \\
\hline 74 & $\mathrm{~T} 41 \mathrm{JF}$ & 1 & $1 \mathrm{c}$ & 1 & + \\
\hline \multicolumn{6}{|c|}{ Republic of Ireland $\dagger$} \\
\hline 75 & A 006022 & 3 & $3 c$ & 3 & + \\
\hline 76 & A006027 & 3 & $3 c$ & & + \\
\hline 77 & A007036 & 1 & $1 \mathrm{a}$ & 1 & \\
\hline 78 & A007040 & 1 & $1 \mathrm{a}$ & & + \\
\hline 79 & D010011 & 2 & $2 \mathrm{a}$ & 2 & + \\
\hline 80 & $\mathrm{Z} 021003$ & 2 & $2 a$ & & + \\
\hline 81 & UCD13 & 1 & $1 \mathrm{~b}$ & 1 & + \\
\hline
\end{tabular}

*RFLP groups 1, 2 and 3 correspond to biological forms Th1, Th2 and Th3, respectively (Seaby, 1987). † Countries in which isolates were collected.

¥Identity confirmed as $T$. harzianum using the criteria of Rifai (1969) by $\mathrm{Dr}$ M. A. J. Williams (International Mycological Institute [IMI], Egham, UK) and isolates 56, 60 and 71 have been deposited with IMI.

+ , Isolates included for RAPD analysis. 


\section{METHODS}

Fungal growth conditions and DNA extraction. Eighty-one isolates of $T$. barzianum (Table 1) were used in this study. All isolates were identified as $T$. barzianum according to the criteria of Rifai (1969). Isolates 1-59 came from Northern Ireland. Isolates 60-74 came from England and were provided by $\mathrm{Dr}$ John Fletcher, ADAS, Wye. Isolates 75-81 came from the Republic of Ireland and were provided by Dr Owen Doyle, UCD, Dublin. Isolate IMI 110150 was obtained from the International Mycological Institute and used only to extract $m t D N A$ for use as a probe for RFLP analysis.

Fungal cultures were maintained on potato dextrose agar (Oxoid) at $25^{\circ} \mathrm{C}$ and mycelium for DNA extraction was grown in liquid shake cultures (120 r.p.m.) at $25^{\circ} \mathrm{C}$ in glucose Casamino acid medium (1 1 contained glucose, $15.0 \mathrm{~g} ; \mathrm{KH}_{2} \mathrm{PO}_{4}$, $1.0 \mathrm{~g} ; \mathrm{MgSO}_{4} .7 \mathrm{H}_{2} \mathrm{O}, 0.5 \mathrm{~g}$; casein hydrolysate, $4.6 \mathrm{~g}$ and $2 \mathrm{ml}$ trace element solution) for $3 \mathrm{~d}$. DNA was extracted from $300 \mathrm{mg}$ freeze-dried mycelial powder essentially following the method of Raeder \& Broda (1985) but with an additional phenol/chloroform extraction step.

For mitochondrial DNA (mtDNA) isolation, total nucleic acid was extracted from $6 \mathrm{~g}$ freeze-dried mycelial powder. Mitochondrial DNA was purified by caesium chloride/bisbenzimide gradient centrifugation (Beckman $\mathrm{Ti} 70$ rotor, $25^{\circ} \mathrm{C}$, 40000 r.p.m., 60 h) following the method of Garber \& Yoder (1983).

Southern blotting, hybridization and autoradiography. DNA was quantified by ethidium bromide fluorescence on a UV transilluminator with known quantities of $\lambda$ DNA (Sambrook et al., 1989). Genomic DNA $(1-2 \mu \mathrm{g})$ was digested with $25 \mathrm{U}$ restriction enzyme until completion at $37^{\circ} \mathrm{C}$ according to the manufacturer's instructions (Promega). Digested DNA was electrophoresed in $0.8 \%(\mathrm{w} / \mathrm{v})$ agarose gels for $13 \mathrm{~h}$ at $60 \mathrm{~V}$ (electrophoresis buffer: $89 \mathrm{mM}$ Tris, $89 \mathrm{mM}$ boric acid, $2 \mathrm{mM}$ EDTA) with HindIII-digested $\lambda$ DNA and/or digested pGEM as molecular size markers (Promega), transferred to a nylon membrane (Hybond N, Amersham) by capillary transfer (Sambrook et al., 1989) and immobilized by baking at $80^{\circ} \mathrm{C}$ for $90 \mathrm{~min}$.

Probes. For ribosomal DNA (rDNA) analysis, Southern blots were probed with plasmid $\mathrm{PMY} 60$ containing a complete rDNA unit from Saccharomyces carlsbergensis Hansen (Verbeet et al., 1983). For mitochondrial genome probing, mtDNA purified from isolates T28JF, ThI and IMI 110150 was used.

Probes were labelled with $\left[\alpha-{ }^{32} \mathrm{P}\right]$ deoxyadenosine $5^{\prime}$ triphosphate (Amersham) using the Prime-a-Gene labelling system (Promega) and separated from unincorporated nucleotides on a G-50 Sephadex column. Hybridization was performed in a hybridization oven (Hybaid) at $65^{\circ} \mathrm{C}$ following the procedure described by Sambrook et al. (1989). The prehybridization wash was for $3 \mathrm{~h}$ and post-hybridization washes consisted of three washes of $30 \mathrm{~min}$ each in $2 \times \mathrm{SSC}$ and $0.1 \%$ SDS, and three washes of $30 \mathrm{~min}$ each in $0.1 \times \mathrm{SSC}$ and $0.1 \%$ SDS. Finally membranes were wrapped with clingfilm and exposed to Hyperfilm $\beta$-max (Amersham) at $-70^{\circ} \mathrm{C}$ using intensifying screens.

PCR amplification. For RAPD analysis, primers A3 (AGTCAGCCAC), A11 (CAATCGCCGT), A13 (CAGCACCCAC), B6 (TGCTCTGCCC), B7 (GGTGACGCAG) and B10 (CTGCTGGGAC), supplied by Operon Technologies, CA, USA, were used. Reaction mixtures contained $5 \mu \mathrm{l}$ of appropriately diluted genomic DNA (20-30 ng), $5 \mu$ l of Taq $10 \times$ buffer, $8 \mu$ l of $100 \mu \mathrm{M}$ each of deoxynucleotide triphosphate (dNTP) mix, $5 \mu \mathrm{l}$ of primer $\left(15 \mu \mathrm{g} \mathrm{m}^{-1}\right), 0 \cdot 25 \mu \mathrm{l}$ of Taq DNA

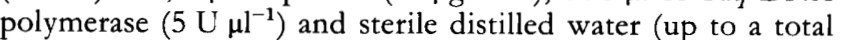
volume of $50 \mu \mathrm{l}$ ). Amplification reactions consisted of 45 cycles in a thermal cycler (Perkin-Elmer-Cetus). Each cycle consisted of $1.5 \mathrm{~min}$ at $94^{\circ} \mathrm{C}, 2 \mathrm{~min}$ at $30^{\circ} \mathrm{C}$ and $3 \mathrm{~min}$ at $72{ }^{\circ} \mathrm{C}$, followed by a final extension time of $7 \mathrm{~min}$ at $72{ }^{\circ} \mathrm{C}$. PCR products $(20 \mu \mathrm{l})$ were visualized in $1.4 \%(\mathrm{w} / \mathrm{v})$ agarose gels stained with ethidium bromide $\left(0 \cdot 4 \mu \mathrm{g} \mathrm{ml}^{-1}\right)$.

For data analysis, each amplified fragment with all six primers was treated as a separate character. DNA fragments of the same size were assumed to represent the same genetic locus and scored as either present or absent. The cluster analysis of the data was done based on a similarity matrix derived from the formula: number of shared characters/total number of characters. The dendrogram was generated by the 'group average' method on the program Genstat 5 (Lawes Agricultural Trust, Rothamsted Experimental Station, Harpenden, UK).

The ITS 1 region of rDNA was amplified using biotinylated ITS 1 and ITS 2 primers (White et al., 1990) supplied by Operon. For each isolate, two $100 \mu \mathrm{l}$ reactions using one of the biotinylated primers with appropriate non-biotinylated primers were performed. PCR mixtures contained diluted genomic DNA (40-50 ng), reaction buffer, $200 \mu \mathrm{M}$ of each dNTP, $0 \cdot 4 \mu \mathrm{M}$ each of primers 1 and 2, and 2.5 units of Taq DNA polymerase; they were subjected to 30 cycles of $1.5 \mathrm{~min}$ at $94{ }^{\circ} \mathrm{C}, 2 \mathrm{~min}$ at $45^{\circ} \mathrm{C}$ and $3 \mathrm{~min}$ at $72^{\circ} \mathrm{C}$.

Sequencing. Template DNA (100 $\mu \mathrm{l})$ was immobilized using $100 \mu \mathrm{l}$ Dynabeads (Dynal, Norway) according to the manufacturer's instructions. Direct solid-phase sequencing (Hultman et al., 1989) was done by the chain-termination method (Sanger et al., 1977) using the non-biotinylated primer as the sequencing primer with a T7 DNA polymerase sequencing kit (Pharmacia). Sequencing reactions and electrophoresis were carried out as described by Gyllensten \& Erlich (1988).

For data analysis, the percentage of shared restriction endonuclease fragments $(F)$ and the nucleotide sequence divergence estimates $(p)$ between various RFLP groups were calculated using the following formulae: $F=\left(2 N_{x y}\right) / N_{x}+N_{y}$ and $p=$ $(-\ln F) / r$, where $N_{x y}$ is the number of shared fragments between two samplings, $N_{x}$ and $N_{y}$ are the total number of fragments in each of the samples and $r$ is the number of nucleotide bases for the restriction enzyme (Nei \& Li, 1979; Nei $\&$ Tajima, 1983). The sequence data were aligned using the Clustal v package (Higgins et al., 1992). Percentage divergence was calculated as follows: [(Ts $+\mathrm{Tv}+\mathrm{I} / \mathrm{D}) /$ (sequence length)] $\times 100$, where Ts is transition, Tv is transversion, $\mathrm{I}$ is insertion and $\mathrm{D}$ is deletion. One or more base $\mathrm{I} / \mathrm{D}$ was scored as one. The length of the smaller sequence was used for computation.

\section{RESULTS}

\section{Analysis of rDNA RFLP patterns}

Ribosomal DNA restriction patterns generated by the enzymes EcoRI, SacI and ClaI placed the 81 isolates of $T$. harzianum into three distinct groups (Table 1). Within each group all isolates gave a similar pattern with each of the enzymes tested. All three groups shared a band of approximately $3.1 \mathrm{~kb}$ in EcoRI digestion (Fig. 1a). A 


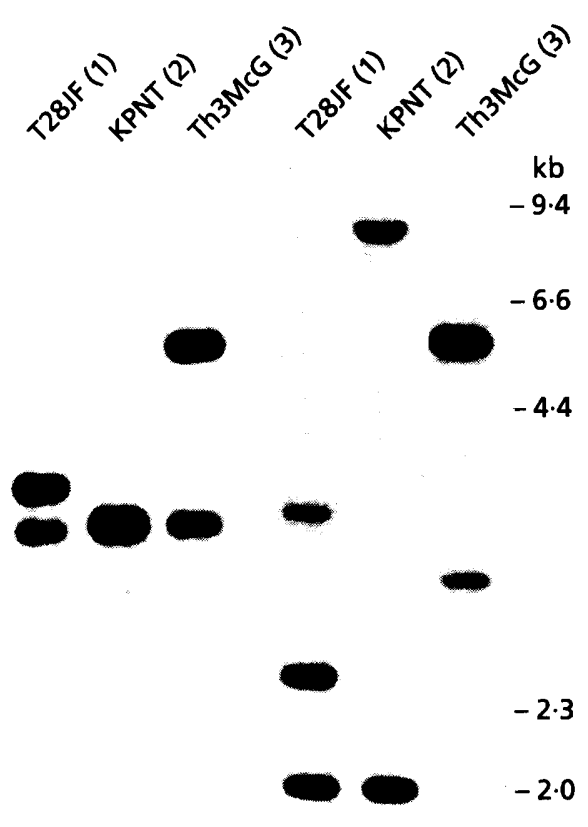

(a)

(b) calculated to be $8-9 \mathrm{~kb}$ for group 1 and 3 isolates and $11-12 \mathrm{~kb}$ for group 2 isolates.

\section{Polymorphisms in mtDNA}

Mitochondrial DNA RFLPs divided the 81 T. barzianum isolates into three major groups $(1,2$ and 3$)$ when probed with mtDNA from the isolate ThI. Groupings were the same as those identified by rDNA analysis. For further analysis, mtDNA extracted from one isolate in each major group was used as a probe to determine the polymorphisms within the group.

Isolates were placed in subgroups according to the limited degree of variation observed within a group (Table 1). Representative isolates of each subgroup from all three major groups were chosen and heterologous hybridizations were carried out. The size of the mitochondrial genome of each group was calculated by summation of fragment sizes (from various digestions) on ethidium bromide stained agarose gels.

Variation in group 1 isolates. mtDNA from isolate T28JF (approximately 38-40 kb) was used to probe HindIII digests of group 1 isolates. Out of 35 isolates, 24 fell into the subgroup $1 \mathrm{a}$ and the remaining 11 isolates formed six more subgroups (1b-1g) (Table 1 ). Restriction enzyme digestion patterns of a representative isolate from each of the seven subgroups are shown in Fig. 2a. HindIII digestion yielded 9-11 fragments, of which seven bands were shared by all seven subgroups. The proportion of shared fragments $(F)$ was between $61 \%$ and $95 \%$ for the various subgroups. EcoRI digestion produced six to eight bands, of which four were common to all subgroups (data not shown); the subgrouping of isolates was similar to that obtained using HindIII.

second band of approximately $3.6 \mathrm{~kb}$ was seen with group 1 isolates and of approximately $4.7 \mathrm{~kb}$ with group 3 isolates. With group 2 isolates, a second band was not detected, but the signal intensity of the $3.1 \mathrm{~kb}$ band was strong, suggesting the presence of two co-migrating fragments. With SacI digestion (Fig. 1b), a common band of approximately $2 \mathrm{~kb}$ was observed with group 1 and 2 isolates. Group 1 isolates differed from group 2 isolates in having two more bands of 3.3 and $2.4 \mathrm{~kb}$, whereas group 2 isolates produced a second band of $6.9 \mathrm{~kb}$. Group 3 isolates yielded two bands of 4.7 and $2.7 \mathrm{~kb}$ with $\mathrm{SacI}$ digestion.

ClaI digestion resulted in three bands for all isolates, of which two bands of approximately $2 \cdot 2$ and $1.1 \mathrm{~kb}$ were common to all isolates. The third band was polymorphic and confirmed the groupings (data not shown).

Two out of the six enzymes used (HindIII and Pst I) yielded a single band for group 1 and 2 isolates (approximately 9 and $12 \mathrm{~kb}$ respectively), whereas rDNA from group 3 isolates was not digested. Group 3 isolates could be distinguished by the presence of a Bam HI site which resulted in a $9 \mathrm{~kb}$ fragment, whereas no Bam HI site was found in the ribosomal repeat units of either group 1 or group 2 isolates.

By summation of the size of fragments from various digestions, the approximate unit length of rDNA was
Variation in group 2 isolates. Restriction fragment patterns generated for group 2 isolates, using HindIII and mtDNA from isolate ThI as probe (approximately 60$62 \mathrm{~kb})$, divided the 36 isolates into five subgroups $(2 \mathrm{a}-2 \mathrm{e})$. Twenty-four isolates (all from Northern Ireland and the Republic of Ireland) formed the large subgroup 2a. bands (Fig. 2b) with 16 bands common to all subgroups. The $F$ values ranged from $78 \%$ to $98 \%$ between the various subgroups. These subgroupings were confirmed by EcoRI digestion (data not presented).

Variation in group $\mathbf{3}$ isolates. Homologous probing with mtDNA from the isolate IMI 110150 (approximately $28-30 \mathrm{~kb})$ separated the 13 isolates of group 3 into five subgroups $(3 a-3 e)$ in both HindIII and EcoRI digestions. Isolates from the Republic of Ireland and England formed subgroups $3 \mathrm{c}$ and $3 \mathrm{~d}$ respectively. Isolates from Northern Ireland were separated into three more subgroups $(3 a, 3 b$ and 3e). HindIII digestion produced 11-13 fragments (Fig. 2c), of which nine were shared by all subgroups with $F$ values ranging from $83 \%$ to $96 \%$.

Heterologous probing. In cross-hybridization experiments using heterologous mtDNA probes, only two or three co-migrating fragments were observed between HindIII digestion of group 2 isolates generated 20-23 


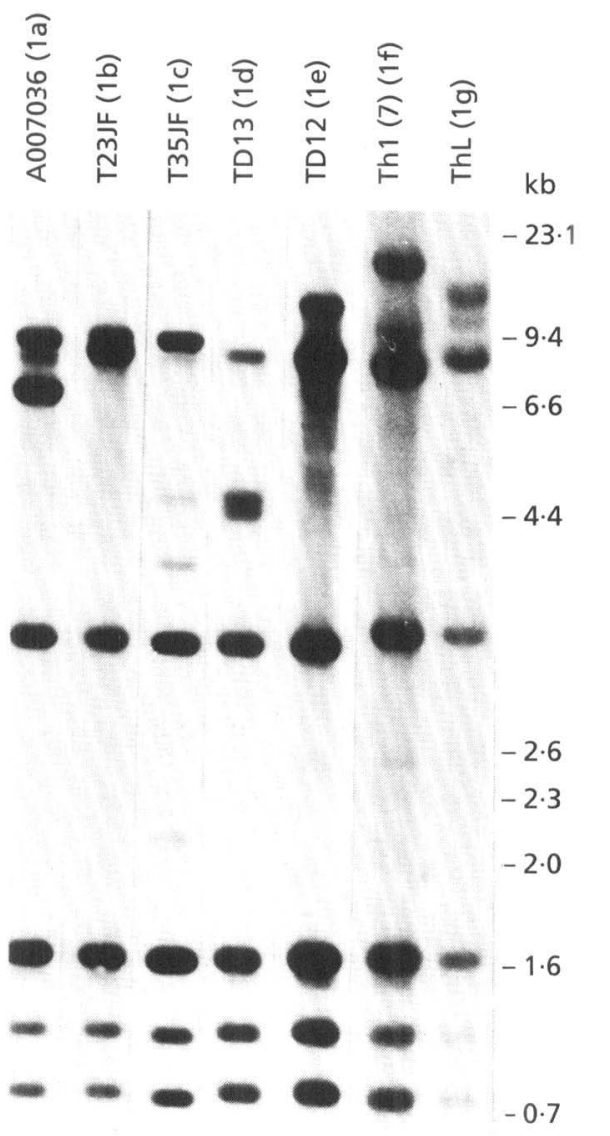

(a)

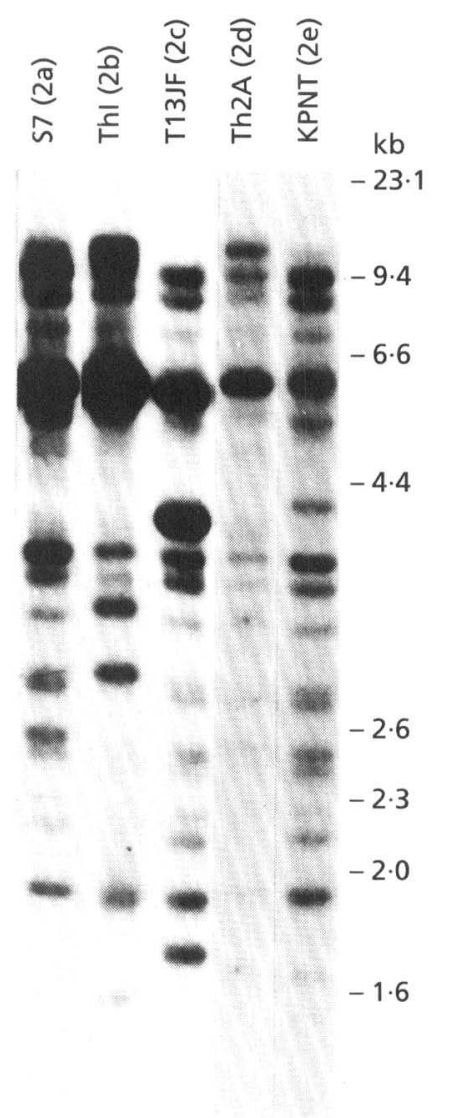

$-0.7$

(b)

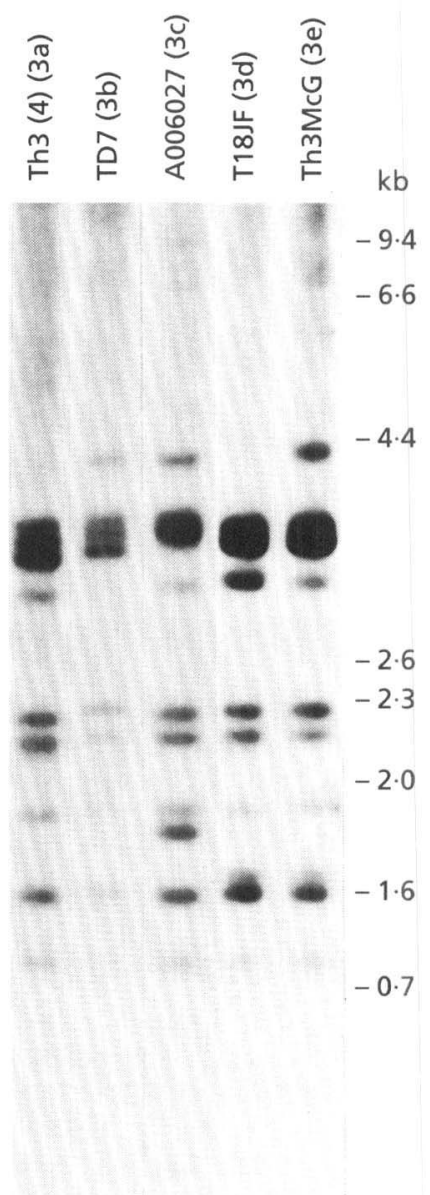

(c)

Fig. 2. mtDNA RFLP patterns of $T$. harzianum isolates digested with HindIII: (a) group 1 isolates probed with mtDNA from the group 1 isolate T28JF; (b) group 2 isolates probed with mtDNA from the group 2 isolate Thl; (c) group 3 isolates probed with mtDNA from the group 3 isolate IMI 110150. Subgroupings of the isolates are given in parentheses; isolates in each group and subgroup are given in Table 1. Molecular size markers refer to HindIII-digested $\lambda$ DNA and digested PGEM.

groups 1,2 and 3 , resulting in low $F$ values (Table 2). The signal intensity was reduced relative to homologous probings. When group 2 isolates were hybridized with heterologous probes (mtDNA from either group 1 or group 3 isolates) very few fragments hybridized and high molecular mass fragments were visible only after prolonged exposure $(7 \mathrm{~d})$.

\section{RAPD analysis of $T$. harzianum isolates}

To estimate the intraspecific diversity of $T$. barzianum isolates from mushroom compost, six RAPD primers were used with 30 randomly chosen isolates. These represented all three major RFLP groups as indicated in Table 1. The RAPD patterns produced by all six primers differentiated the 30 isolates, with some exceptions, into the same three groups as revealed by RFLP analyses. None of the primers used unified the three groups. Fig. 3 illustrates the RAPD pattern of eight isolates from each group with primers $A 3$ and A13 (data for primers A11, B6, B7 and B10 are not presented).

The isolates formed three main clusters on the dendrogram (Fig. 4), corroborating the results from RFLP analyses. Within cluster 1 , representing group 1 isolates, similarity varied from $72 \%$ to $100 \%$. Group 2 isolates in cluster 2 were identical. The third cluster, representing group 3 isolates, showed similar variation to group 1 isolates, of $70 \%$ to $100 \%$. Cluster analysis suggests a closer relationship between groups 1 and 2 than between either of these two groups and group 3.

\section{Sequence analysis of the ITS 1 region}

Sequencing of the ITS 1 region of $18 T$. harzianum isolates (indicated in Table 1) revealed that there were three 

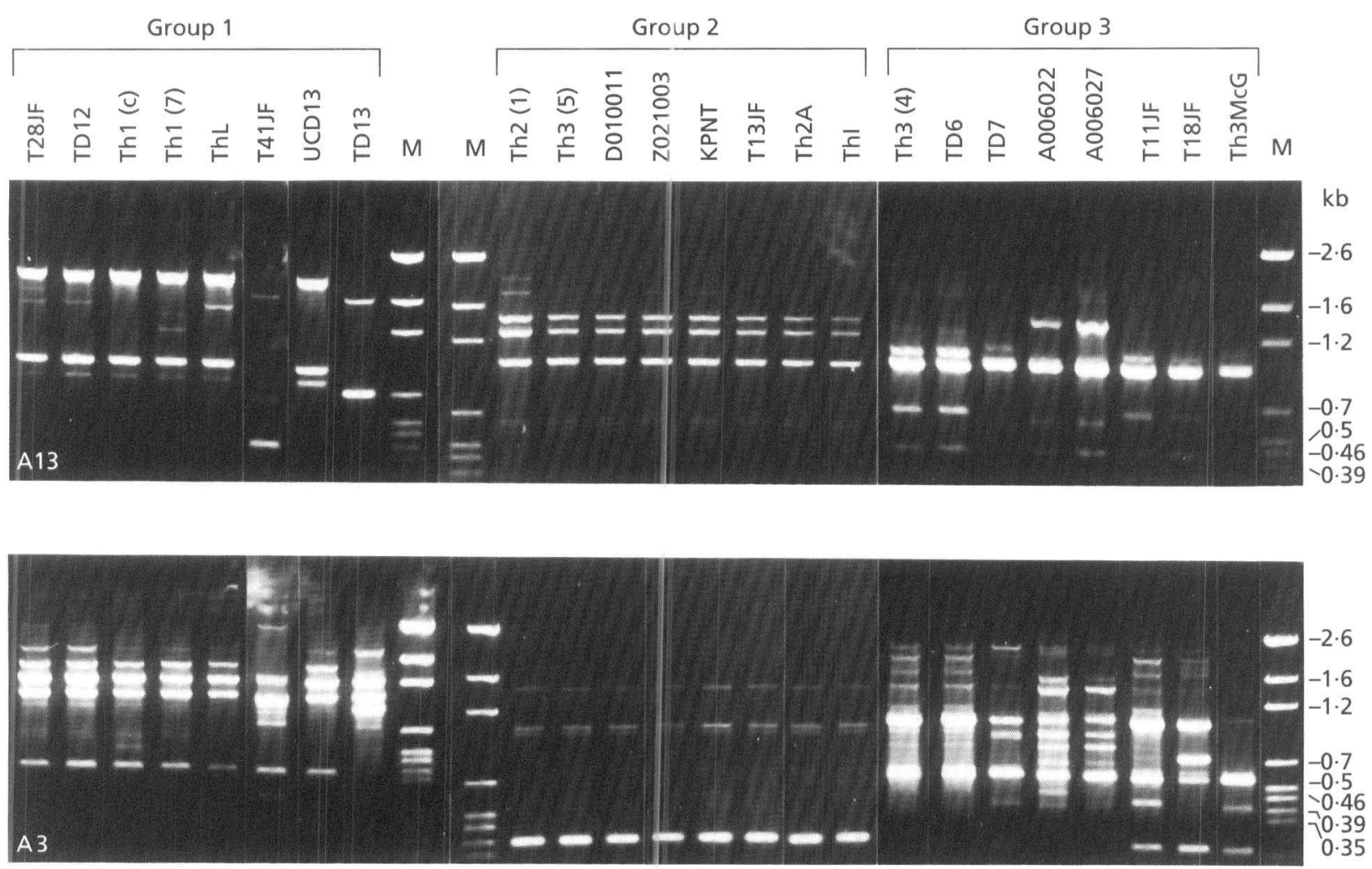

Fig. 3. Randomly amplified polymorphic DNA patterns of $T$. harzianum isolates with primers $A 13$ and $A 3$ (M, digested PGEM used as molecular size marker).

distinct ITS types 1, 2 and 3 (Fig. 5), corresponding to the groups 1, 2 and 3 from RFLP and RAPD analyses. The ITS 1 sequence of all five group 2 isolates (202 bp) was identical. The ITS 1 sequence of all six group 3 isolates (182 bp) was identical. Within the seven group 1 isolates (201-203 bp), insertion/deletion of two thymines (at positions 115 and/or 151 and 168) was the only variation observed within the group (Fig. 5). Group 1 isolates

Table 2. Percentage of shared fragments $(F)$ within and between the $T$. harzianum groups from homologous and heterologous hybridizations of mtDNA

Isolates in each group are given in Table 1.

\begin{tabular}{|lllcc|}
\hline \multirow{2}{*}{$\begin{array}{l}\text { Probe } \\
\text { DNA }\end{array}$} & Endonuclease & \multicolumn{3}{c|}{ Target DNA } \\
\cline { 3 - 5 } & & Group 1 & Group 2 & Group 3 \\
\hline \multirow{2}{*}{ Group 1 } & HindIII & $60-94$ & $23-26$ & $20-25$ \\
& EcoRI & $66-83$ & $12-13$ & $16-18$ \\
Group 2 & HindIII & $20-45$ & $78-97$ & $13-22$ \\
& EcoRI & $22-38$ & $70-97$ & $14-21$ \\
Group 3 & HindIII & $22-25$ & $17-19$ & $81-95$ \\
& EcoRI & $28-32$ & $29-33$ & $75-92$ \\
\hline
\end{tabular}

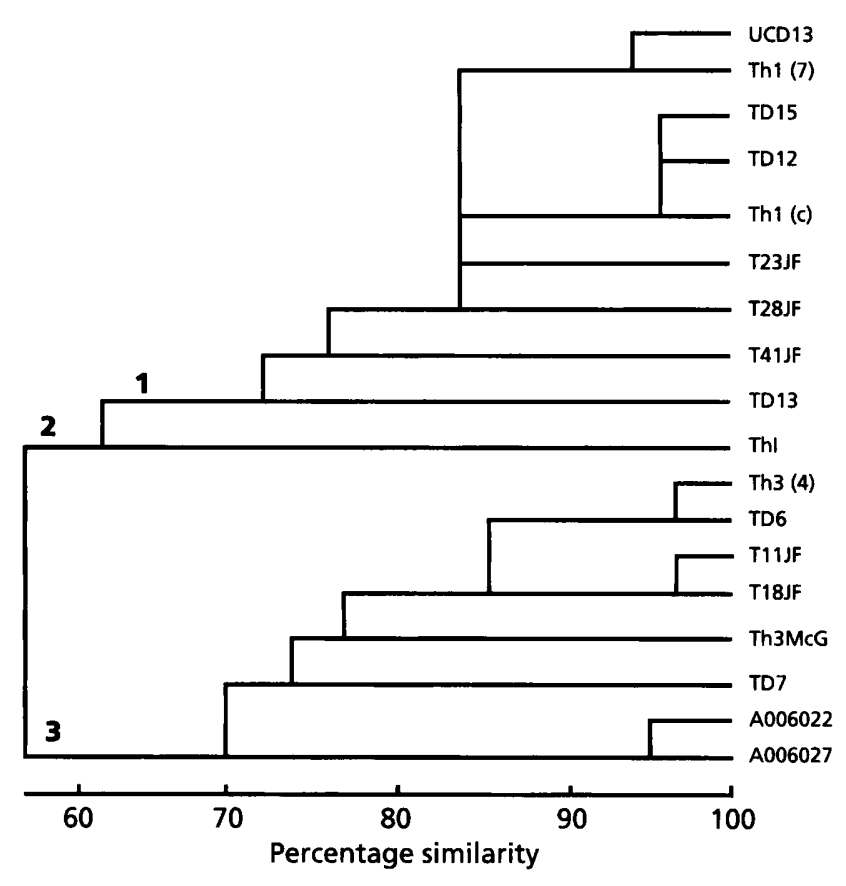

Fig. 4. Clustering of isolates of $T$. harzianum from pairwise comparison of RAPDs by the group average method (see Table 1 for details of isolates). Isolate UCD13 in cluster 1 is representative of group 1 isolates ThL, A001040 and Th1M. Isolate Thl in cluster 2 is representative of group 2 isolates Th2 shiitake, Th2(1), Th3(5), D010011, Z021003, T9JF, KPNT, T13JF and Th2A. 

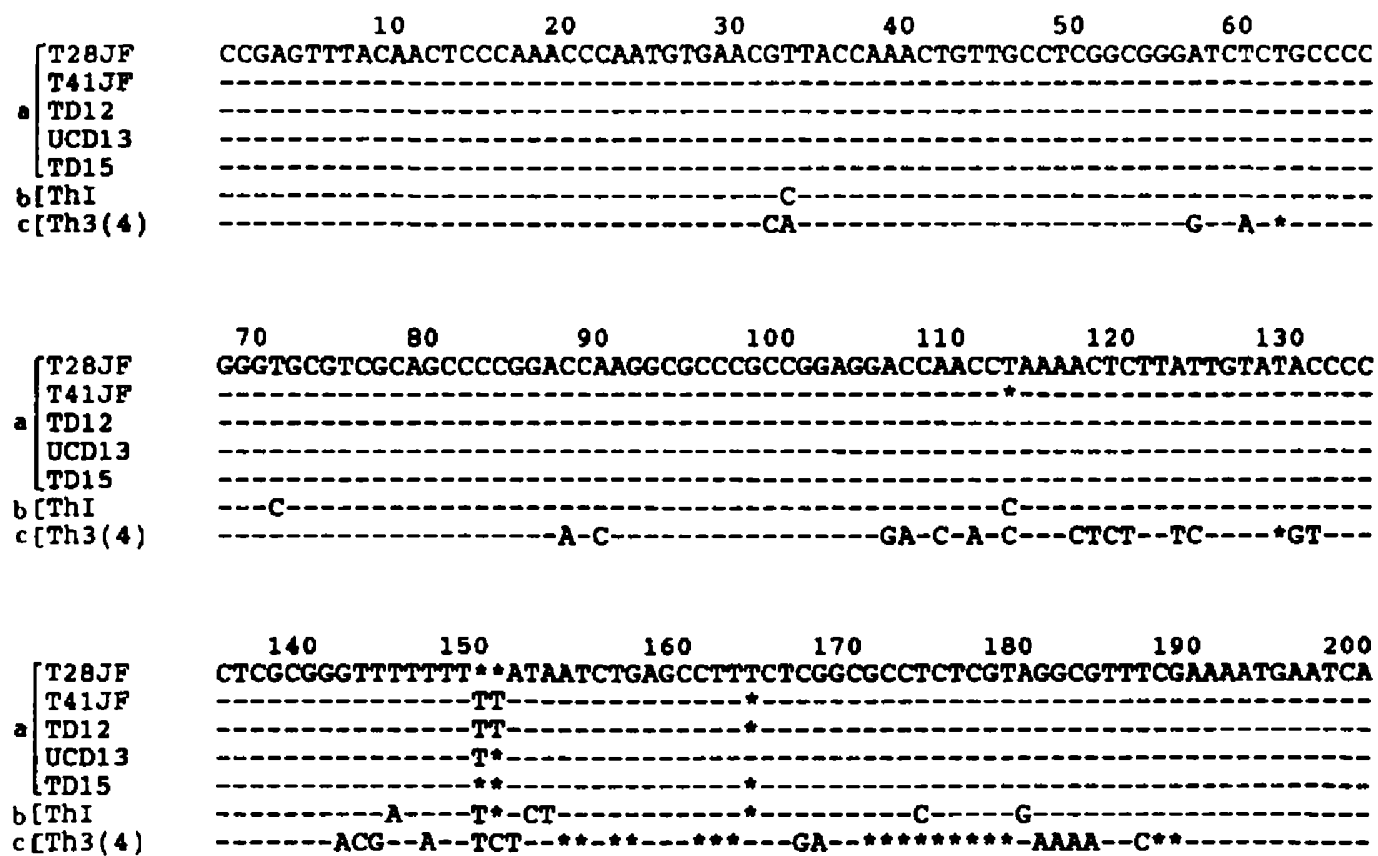

Fig. 5. Nucleotide sequence of the ITS 1 region of $T$. harzianum isolates. (a) Representatives of group 1 isolates (type 1 sequences). Isolate A007036 had an identical sequence to isolate T28JF. Isolate TD1 had an identical sequence to isolate TD 15. (b) Representative of group 2 isolates (type 2 sequence). Th2A, Thl, Th2(1), KPNT and D010011 had an identical sequence. (c) Representative of group 3 isolates (type 3 sequence). Th3(4), Th3(7), Th3McG, TD7, T11JF, and A006022 had an identical sequence. Identical bases are indicated by -. For list of isolates, see Table 1.

Table 3. Divergence between the nucleotide sequences of the ITS 1 region of $T$. harzianum isolates

\begin{tabular}{|ccccc|}
\hline $\begin{array}{c}\text { ITS } 1 \\
\text { type* }\end{array}$ & $\begin{array}{c}\text { Transition } \\
\text { (Ts) }\end{array}$ & $\begin{array}{c}\text { Transversion } \\
\text { (Tv) }\end{array}$ & $\begin{array}{c}\text { Insertion/ Percentage } \\
\text { Deletion } \\
\text { (I/D) } \dagger\end{array}$ \\
\cline { 2 - 5 } divergence $\ddagger$
\end{tabular}

* ITS I types 1, 2 and 3 relate to RFI,P and RAPD groups 1, 2 and 3. Isolates representing the ITS types are given in Table 1.

tOne or more base length differences were scored as one.

$\ddagger$ Percentage divergence $=[(T s+T \mathrm{v}+\mathrm{I} / \mathrm{D}) /($ sequence length $)]$ $\times 100$

showed $4.7 \%$ divergence from group 2 isolates, and group 1 and group 2 isolates showed $20.0 \%$ and $22.9 \%$ divergence from group 3 isolates respectively (Table 3 ).

\section{DISCUSSION}

A number of Trichoderma spp. have been isolated from mushroom compost but aggressive colonization appears to be restricted to some isolates of $\Gamma$. harzianum (Seaby, 1987: Doyle, 1991). T. harzianum isolares from mushroom compost have been differentiated into three biological forms by Seaby (1987) and Doyle (1991). Howcver, delineation of the three forms is not always reliable using biological characteristics, and on many occasions group 2 isolaces were incorrectly identified as group 1 and group 3 on the basis of time and pattern of sporulation, e.g. isolates 4, 53, 61 and 65 (Table 1) were identified as group 1 and isolates 33.39 and 41 (Table 1) were identified as group 3. Lnambiguous differentiation of aggressive Th2 isolates from morphologically identical non-(or less) aggressive $T$ th 1 and $T h 3$ forms is essential when assessing the risk to mushroom compost from Th2 isolates or when assessing the biological variation within Th2 isolates.

The results reported in the present paper indicare the value of molecular techniques in isolate differentiation for $T$. barzianum. RFI.P analysis of the generally conserved ribosomal RNA (rDNA) gene block separated $T$. barzianum into three distinct groups within which there was no variation. The size of the rDNA gene block varied between 8 and $9 \mathrm{kt}$, for group 1 and group 3 isolates, and between 11 and $12 \mathrm{~kb}$ for group 2 isolates. This level of size variation within a species is unusual but similar variation has becn reported for Colletotrichum glocosporioides (Braithwaite et al., 1990; Hodson et al., 1993), where again species concept is ambiguous.

The level of variation between groups was greatest when comparisons were made using $\mathrm{mtDN} A$. As with rDNA RFLP and RAPD analyses, mtDN $A$ restriction enzyme fragment patterns separated $T$. barziantum isolates into the same three groups. Within a group the variation was 
generally low, with $p$ values similar to those reported within species in genera such as Phytopbthora (Förster et al., 1988), Aspergillus (Moody \& Tyler, 1990b) and Colletotrichum (Sreenivasaprasad et al., 1992). Between groups the variation was high, with few shared bands, resulting in $F$ values generally lower than or similar to those reported for different species of Phytophthora of 43-68 \% (Förster et al., 1988) and Pythium spp. of 20-67\% (Martin \& Kistler, 1990).

Sequence analyses of the rRNA genes and the non-coding spacer regions have provided valuable taxonomic information for a range of organisms (Förster et al., 1990; Illingworth et al., 1991; Olsen et al., 1986; Sreenivasaprasad et al., 1992). Analysis of the ITS 1 region of 18 T. harzianum isolates showed no sequence variation within either group 2 isolates or group 3 isolates and only limited variation (two insertions/deletions) among group 1 isolates. Divergence values between groups suggest a closer relationship between groups 1 and $2(4.7 \%)$ than the more distant relationship between these two groups and group 3 (approximately $20 \%$ ). Divergence values for other genera vary. Lee \& Taylor (1992) reported values of only $2 \%$ between Phytophthora spp. but values of $6 \%$ and $15 \%$ have been reported between isolates of Colletotrichum acutatum (Sreenivasaprasad et al., 1992) and Fusarium sambucinum (O'Donnell, 1992) respectively.

Genetic uniformity within the aggressive colonizing group 2 isolates may support the hypothesis that outbreaks of Trichoderma within the British Isles could have originated from a single source, although minor differences in $\mathrm{mtDNA}$ could distinguish Irish isolates from those in Great Britain. It is interesting to note that international culture collections contain isolates of $T$. barzianum that are identical to either group 1 or group 3 isolates but no Trichoderma cultures received from these collections showed similarity to group 2 isolates (S. Muthumeenakshi, unpublished). These data also refute: the view that the aggressive group 2 forms of $T$. barzianum have been selected from populations of group 1 or 3 isolates.

Although the morphotaxonomic characteristics of isolates of these three groups fall within the broad range of variation described for the species aggregate $T$. harzianum (Rifai, 1969), the molecular data could suggest their separation into three DNA-based species (Reynolds \& Taylor, 1991). An example of each group has been deposited with the International Mycological Institute. Sexual compatibility studies could possibly be used to support this hypothesis; however, the teleomorph stage is difficult to induce in culture. Further supporting evidence may be provided by assessing the level of inter- and intraspecific molecular variation between other members of the genus Trichoderma.

\section{ACKNOWLEDGEMENTS}

The authors would like to thank Drs J. T. Fletcher and O. Doyle for supplying fungal isolates. They also thank $\mathrm{Dr}$ M. A. J. Williams, International Mycological Institute, for con- firmation of identity of representative isolates from each of the three groups in this study as T. harzianum, and Ms S. Watson for analysis of RAPD data. This work was partially funded by the Horticultural Development Council.

\section{REFERENCES}

Bissett, J. (1991). A revision of the genus Trichoderma. II. Infrageneric classification. Can J Bot 69, 2357-2372.

Braithwaite, K. S., Irwin, J. A. G. \& Manners, J. M. (1990). Restriction fragment length polymorphisms in Colletotrichum gloeosporioides infecting Stylosanthes spp. in Australia. Mycol Res 94, 1129-1137.

Buchko, J. \& Klassen, G. R. (1990). Detection of length heterogeneity in the ribosomal DNA of Pythium ultimum by amplification of the intergenic region. Curr Genet 18, 203-205.

Chen, W., Hoy, W. \& Schneider, R. W. (1992). Species-specific polymorphisms in transcribed ribosomal DNA of five Pythium species. Exp Mycol 16, 22-34.

Doyle, O. (1991). Trichoderma green mould - update. Irish Musbroom Rev 3, 13-17.

Fletcher, J. T. (1990). Trichoderma and Penicillium diseases of Agaricus bisporus. A literature review for the Horticultural Development Council. London: ADAS.

Förster, H., Kinscherf, T. G., Leong, S. A. \& Maxwell, D. P. (1988). Estimation of relatedness between Phytophthora species by analysis of mitochondrial DNA. Mycologia 80, 466-478.

Förster, H., Coffey, M. D., Ellwood, H. \& Sogin, M. L. (1990). Sequence analysis of the small subunit ribosomal RNAs of three zoosporic fungi and implications for fungal evolution. Mycologia 82, 306-312.

Garber, R. C. \& Yoder, O. C. (1983). Isolation of DNA from filamentous fungi and separation into nuclear, mitochondrial, ribosomal and plasmid components. Anal Biochem 135, 416-422.

Gaudet, J., Julien, J., Lafay, J. F. \& Brygoo, Y. (1989). Phylogeny of some Fusarium species, as determined by large-subunit rRNA sequence comparison. Mol Biol Evol 6, 227-242.

Gyllensten, U. B. \& Erlich, H. A. (1988). Generation of singlestranded DNA by the polymerase chain reaction and its application to direct sequencing of the $H L A-D Q A$ locus. Proc Natl Acad $S_{c i}$ US A 85, 7652-7656.

Higgins, D. G., Bleasby, A. J. \& Fuchs, R. (1992). Clustal v: improved software for multiple sequence alignment. Comput $A p p l$ Biosci 8, 189-191.

Hodson, A., Mills, P. R. \& Brown, A. E. (1993). Ribosomal and mitochondrial DNA polymorphisms in Colletotrichum gloeosporioides isolated from tropical fruits. Mycol Res 97, 329-335.

Hultman, T., Ståhl, S., Hornes, E. \& Uhlén, M. (1989). Direct solid phase sequencing of genomic and plasmid DNA using magnetic beads as solid support. Nucleic Acids Res 17, 4937-4946.

Illingworth, C. A., Andrews, J. H., Bibeau, C. \& Sogin, M. L. (1991). Phylogenetic placement of Athelia bombacina, Aureobasidium pullulans and Colletotrichum gloeosporioides inferred from sequence comparisons of small-subunit ribosomal RNAs. Exp Mycol 15, 65-75.

Lee, S. B. \& Taylor, J. W. (1992). Phylogeny of five fungus-like protoctistan Pbytopbthora species inferred from the internal transcribed spacers of ribosomal DNA. Mol Biol Evol 9, 636-653.

Levy, M., Romao, J., Marchetti, M. A. \& Hamer, J. E. (1991). DNA fingerprinting with a dispersed repeated sequence resolves pathotype diversity in the rice blast fungus. Plant Cell 3, 95-102.

Martin, F. N. \& Kistler, H. C. (1990). Species-specific banding 
patterns of restriction endonuclease-digested mitochondrial DNA from the genus Pytbium. Exp Mycol 14, 32-46.

Meyer, W., Morawetz, R., Börner, T. \& Kubicek, C. P. (1992). The use of DNA-fingerprint analysis in the classification of some species of the Trichoderma aggregate. Curr Genet 21, 27-30.

Moody, S. F. \& Tyler, B. M. (1990a). Restriction enzyme analysis of mitochondrial DNA of the Aspergillus flavus group: A. flavus, A. parasiticus and A. nomius. Appl Environ Microbiol 56, 2441-2452.

Moody, S. F. \& Tyler, B. M. (1990b). Use of nuclear DNA restriction fragment length polymorphisms to analyze the diversity of the Aspergillus flavus group: A. flavus, $A$. parasiticus and A. nomius. Appl Environ Microbiol 56, 2453-2461.

Nei, M. \& Li, W. H. (1979). Mathematical model for studying genetic variation in terms of restriction endonucleases. Proc Nat Acad Sci US A 76, 5269-5273.

Nei, M. \& Tajima, F. (1983). Maximum likelihood estimation of the number of nucleotide substitutions from restriction sites data. Genetics 105, 207-217.

O'Donnell, K. (1992). Ribosomal DNA internal transcribed spacers are highly divergent in the phytopathogenic ascomycete Fusarium sambucinum (Gibberella pulicaris). Curr Genet 22, 213-220.

Olsen, G. J., Lane, D. J., Giovannoni, S. J., Pace, N. R. \& Stahl, D. A. (1986). Microbial ecology and evolution: a ribosomal RNA approach. Annu Rev Microbiol 40, 337-365.

Raeder, U. \& Broda, P. (1985). Rapid preparation of DNA from filamentous fungi. Lett Appl Microbiol 1, 17-20.

Reynolds, D. R. \& Taylor, J. W. (1991). DNA specimens and the 'International code of botanical nomenclature'. Taxon 40, 311-315.

Rifai, M. A. (1969). A revision of the genus Trichoderma. Commonw Mycol Inst Mycol Pap no. 116, pp. 1-56.
Sambrook, J., Fritsch, E. F. \& Maniatis, T. (1989). Molecular Cloning: a Laboratory Manual, 2nd edn. Cold Spring Harbor, NY: Cold Spring Harbor Laboratory.

Sanger, F. S., Nicklen, S. \& Coulson, A. R. (1977). DNA sequencing with chain-terminating inhibitors. Proc Natl Acad Sci USA 74, 5463-5467.

Seaby, D. A. (1987). Infection of mushroom compost by Trichoderma species. Musbroom J 179, 355-361.

Seaby, D. A. (1989). Further observations on Trichoderma. Musbroom $J$ 197, 147-151.

Sreenivasaprasad, S., Brown, A. E. \& Mills, P. R. (1992). DNA sequence variation and interrelationships among Colletotrichum species causing strawberry anthracnose. Physiol Mol Plant Pathol 41, 265-281.

Vaillancourt, L. J. \& Hanau, R. M. (1992). Genetic and morphological comparisons of Glomerella (Colletotrichum) isolates from maize and from sorghum. Exp Mycol 16, 219-229.

Verbeet, M. Ph., Klootwijk, J., Heerikhuizen, H., Fontijn, R., Vreugdenhil, E. \& Planta, R. J. (1983). Molecular cloning of the rDNA of Saccharomyies rosei and comparison of its transcription initiation region with that of Saccharomyces carlsbergensis. Gene 23, 53-63.

White, T. J., Bruns, T., Lee, S. \& Taylor, J. (1990). Amplification and direct sequencing of fungal ribosomal RNA genes for phylogenetics. In PCR Protocols. A Guide to Methods and Applications, pp. 315-322. Edited by M. A. Innis, D. H. Gelfand, J. J. Sninsky \& T. J. White. San Diego: Academic Press.

Received 27 July 1993; revised 20 October 1993; accepted 15 November 1993. 